\title{
Homo Ignorans: Deliberately Choosing Not to Know
}

Perspectives on Psychological Science 2016, Vol. 11(3) 359-372 (C) The Author(s) 2016 Reprints and permissions: sagepub.com/journalsPermissions.nav DOI: $10.1177 / 1745691616635594$ pps.sagepub.com

\section{Ralph Hertwig ${ }^{1}$ and Christoph Engel ${ }^{2}$}

${ }^{1}$ Center for Adaptive Rationality, Max Planck Institute for Human Development, Berlin, Germany, and

${ }^{2}$ Max Planck Institute for Collective Goods, Bonn, Germany

\begin{abstract}
Western history of thought abounds with claims that knowledge is valued and sought. Yet people often choose not to know. We call the conscious choice not to seek or use knowledge (or information) deliberate ignorance. Using examples from a wide range of domains, we demonstrate that deliberate ignorance has important functions. We systematize types of deliberate ignorance, describe their functions, discuss their normative desirability, and consider how they can be modeled. To date, psychologists have paid relatively little attention to the study of ignorance, let alone the deliberate kind. Yet the desire not to know is no anomaly. It is a choice to seek rather than reduce uncertainty whose reasons require nuanced cognitive and economic theories and whose consequences-for the individual and for society—require analyses of both actor and environment.
\end{abstract}

\section{Keywords}

ignorance, homo ignorans, anticipated emotions, rationality, strategic ignorance, uncertainty, emotion regulation

Yet ah! why should they know their fate?

Since sorrow never comes too late,

And happiness too swiftly flies.

Thought would destroy their paradise.

No more; where ignorance is bliss,

'Tis folly to be wise.

(Gray, 1747)

The old saw "What you don't know won't hurt you" turns out to be false at a deeper level. Just the contrary is true "It is just what you don't know that will hurt you." ... Ignorance makes real choice impossible.

(Maslow, 1963)

When James Watson, co-discoverer of the structure of DNA, agreed to have his genome sequenced and released, he had one request: Information about the apolipoprotein E gene, associated with late-onset Alzheimer's disease, should not be shared, even with him (Wheeler et al., 2008). What made this quintessential knowledge-seeker shrink from this information?

\section{The Human Desire to Know}

Knowledge is valued; knowledge is sought. Western history of thought abounds with examples. Adam and Eve could not help but eat from the tree of knowledge. The first line in Aristotle's Metaphysics reads: "All men, by nature, desire to know" (Ross, 1924, p. 255). English philosophers Thomas Hobbes and Francis Bacon celebrated curiosity and the pleasures of learning. Hobbes located curiosity among the passions and considered it a kind of "perpetuum mobile of the soul" (Daston \& Park, 2001, p. 307): Curiosity is a pure desire, distinguished "by a perseverance of delight in the continual and indefatigable generation of Knowledge, [which] exceedeth the short vehemence of any carnall Pleasure" (Hobbes, 1651/1968; p. 124). Similarly, Bacon said of knowledge: "[T]here is no satiety, but satisfaction and appetite are perpetually interchangeable (Montagu, 1841, p. 250).

\section{Corresponding Author:}

Ralph Hertwig, Center for Adaptive Rationality, Max Planck Institute for Human Development, Lentzeallee 94, 14195 Berlin, Germany E-mail: hertwig@mpib-berlin.mpg.de 
Modern psychology has echoed these views and portrayed humans as possessing an emotion-like urge to know (Silvia, 2008) or an instinct-like "burning curiosity" (Maslow, 1963, p. 114). Building on Carnap's (1947, pp. 138-141) "principle of total evidence," philosophers have argued that utility maximizers use all freely available evidence when estimating a probability (Good, 1967), and economists have contended that utility maximizers always prefer more information to less (Blackwell, 1953). Legal scholars claim that more knowledge promotes the veracity of judgments and facilitates settlement (Loewenstein \& Moore, 2004). Economic models often assume that more knowledge translates into greater bargaining power (references in Conrads \& Irlenbusch, 2013). Psychoanalysts help individuals to liberate themselves from their "ostrich-like policy" of repressing painful knowledge (Freud, 1950, p. 152). Knowledge is valued; knowledge is sought.

\section{The Human Desire Not to Know ${ }^{1}$}

In today's aging societies, the risk of outliving personal assets is real. Economic life-cycle models suggest spending those assets optimally; that is, tailoring consumption patterns such that assets reach zero at death (Modigliani, 1986). To plan accordingly, however, retirees need at least one crucial piece of information: the date of their death. And do we mortals-as opposed to our economically rational alter egos-really want to know exactly when we are going to die? In order to have a "good" death, perhaps we should. The medieval Ars Moriendi literature warns that a sudden death robs people of the opportunity to repent their sins. From this perspective, prisoners facing execution are "fortunate"-they know the hour of their death (Bellarmine, 1989).

Although humans are often portrayed as informavores, the circumstances under which they refrain from acquiring or consulting information are many and varied. Take, for instance, individuals at risk of Huntington's disease. Nearly everyone with the defective gene who lives long enough will go on to develop this devastating condition. Yet only $3 \%$ to $25 \%$ of those at high risk opt to take the near-perfect test available to identify carriers of the gene (e.g., Creighton et al., 2003; Yaniv, Benador, \& Sagi, 2004). Similarly, up to $55 \%$ of people who decide to be tested for HIV subsequently do not return to learn their result (Hightow et al., 2003).

Knowledge is not always sought (Ullmann-Margalit, 2000). The Stasi, East Germany's secret police, recruited vast networks of civilian informers-colleagues, friends, and even spouses-to spy on anyone deemed disloyal. When East Germany ceased to exist, people were allowed to consult their files to see who had informed on them, sometimes with heartbreaking results (Jones, 2014)_but not everybody wanted to know. Nobel laureate Günter Grass, for example, a frequent visitor to East Germany, refused to find out which of his friends and colleagues had spied on him (Hage \& Thimm, 2010).

The reality, functions, and rationality of this epistemological abstinence are our focus in this article. We are not interested in ignorance, per se (Gross \& McGoey, 2015; Merton, 1987; Moore \& Tumin, 1949; Schneider, 1962), in the institutional "production" of ignorance (Proctor \& Schiebinger, 2008) or in the suppression of unwanted memories (Anderson \& Green, 2001). In addition, we do not doubt that ignorance can have enormous individual and collective costs (e.g., Marshall, 2014). Our concern is deliberate ignorance, defined as the conscious individual or collective choice not to seek or use information (or knowledge; we use the terms interchangeably). We are particularly interested in situations where the marginal acquisition costs are negligible and the potential benefits potentially large, such that-from the perspective of the economics of information (Stigler, 1961)—acquiring information would seem to be rational (Martinelli, 2006).

We believe that deliberate ignorance is anything but a rare departure from the otherwise unremitting quest for knowledge and certainty: It is an underrated mental tool that exploits the sometimes ingenious powers of ignorance. We therefore posit that psychological science has erred in choosing to remain largely ignorant on the topic of deliberate ignorance. In the remainder of this article, we present a roadmap for overcoming this blind spot. The next section is descriptive: We demonstrate that deliberate ignorance is widespread and propose a taxonomy that brings structure to the rich body of examples provided. The third section is normative: Is deliberate ignorance a good thing? If so, when, for whom-and why? The concluding section sketches out a research agenda: How can descriptive and normative analysis be turned into testable propositions? What are the most promising avenues for empirically testing those propositions? Is there room for an overarching theory of deliberate ignorance? What would be needed to derive policy recommendations?

\section{A Taxonomy of Deliberate Ignorance}

Mainstream social and behavioral science has long skirted the topic of ignorance ("a certain sociological ignorance of ignorance"; Abbott, 2010, p. 174) or treated it as a social problem in need of eradication (Ungar, 2008). Yet sociologists, philosophers, and anthropologists have recently come to see ignorance as an object of study with important epistemological and political implications (Gross \& McGoey, 2015; High, Kelly, \& Mair, 2012; Proctor \& Schiebinger, 2008). Psychologists, however, have barely been involved in the new study of ignorance 


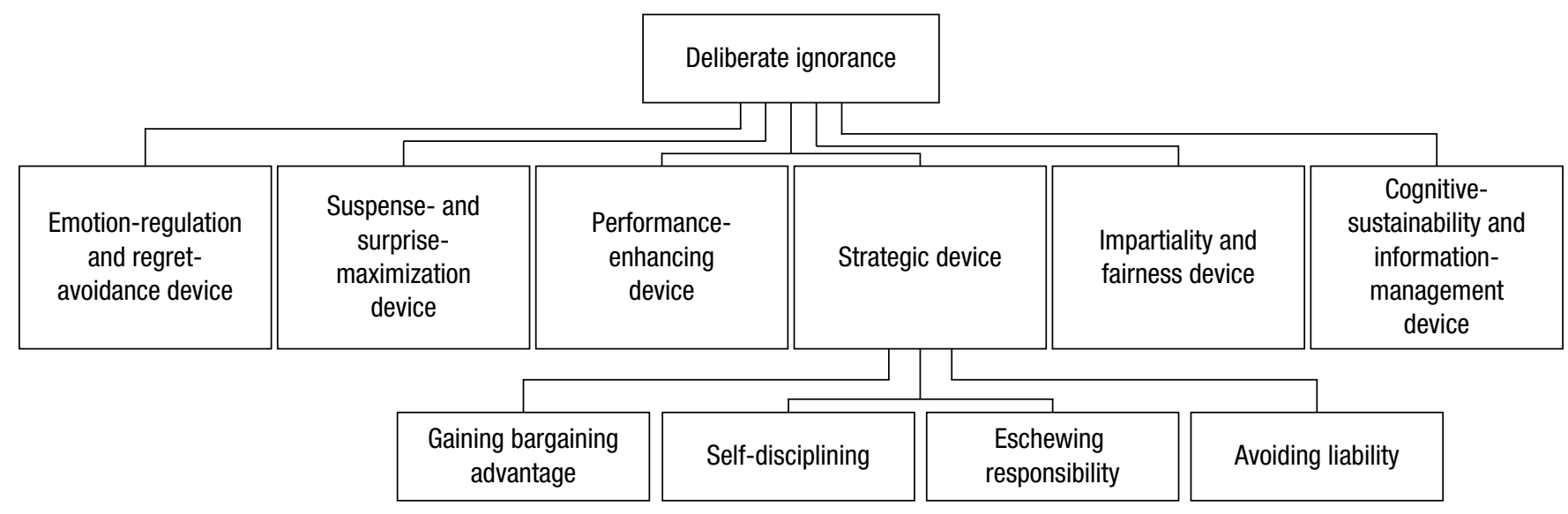

Fig. 1. Taxonomy of types of deliberate ignorance.

or deliberate ignorance (although selective exposure is pertinent to it; Hart et al., 2009). Against this background, we propose the taxonomy outlined in Figure 1. Our taxonomy is just that: an attempt at organizing the evidence. An important next step will be theory building-and we return to promising avenues for theorizing later. But first, it is important to recognize the landscape of deliberate ignorance. The taxonomy maps out what is, in large parts, uncharted empirical and conceptual territory in psychology.

\section{Deliberate ignorance as an emotion- regulation and regret-avoidance device}

People can manipulate their beliefs by selecting the sources of information they consult (Akerlof \& Dickens, 1982) and ignoring some sources altogether. Information avoidance (or defensive avoidance, Howell \& Shepperd, 2013; vs. protective ignorance, Yaniv et al., 2004) has been defined as "any behavior intended to prevent or delay the acquisition of available but potentially unwanted information" (Sweeny, Melnyk, Miller, \& Shepperd, 2010, p. 341). It has primarily been studied in the health domain (Howell \& Shepperd, 2012; Melnyk \& Shepperd, 2012; but see also Shani, van de Ven, \& Zeelenberg, 2012). People may avoid potentially threatening health information because it compromises cherished beliefs; they fear loss of autonomy (e.g., a grueling medical regimen); they anticipate mental discomfort, fear, and cognitive dissonance; or they want to keep hope alive.

On a pragmatic level, medical information may have material implications. People with the Huntington's disease gene may fear stigmatization, discrimination in the workplace, and loss of medical or insurance benefits (Wahlin, 2007). In addition, once an irreversible decision has been made (e.g., to undergo a risky treatment), a person may want to avoid regret by not seeking information that suggests a different decision might have produced a better outcome (Van Dijk \& Zeelenberg, 2007).

The regulatory function of deliberate ignorance may extend to a wider range of domains (e.g., to investors who ignore their portfolios in downturns; e.g., Karlsson, Loewenstein, \& Seppi, 2009) and to emotions, such as social and moral emotions (Elster, 1996; Hutcherson \& Gross, 2011). One such emotion is envy. Pay secrecy can be a firm's strategy to hide pay inequality. Among employees, choosing not to discuss one's pay with one's colleagues can be a conscious strategy to avoid envy and its potentially detrimental effects on job satisfaction.

\section{Deliberate ignorance as a suspense- and surprise-maximization device}

Suppose someone is planning to spend the weekend bingeing on the new season of her favorite TV drama. Will she appreciate a friend giving her a preview? Hardly. People attend soccer games and read mystery novels for the drama. Revealing the ending would spoil their fun. Any policy designed to maximize suspense or surprise will reveal key outcomes (e.g., your birthday present) only at the last minute (see Ely, Frankel, \& Kamenica, 2015 , and references therein). ${ }^{2}$

\section{Deliberate ignorance as a performance-enhancing device}

A common belief in psychology and beyond is that presenting learners with information on their task performance is a powerful and effective way to boost performance. Yet feedback has also been shown to reduce performance under some circumstances (Kluger \& DeNisi, 1996), such as when it causes attention to be directed away from the task to the self, depleting the 
cognitive resources needed for the task. It has also been suggested that feedback revealing large discrepancies between aspired-for and actual performance triggers arousal that, in turn, impairs performance (Kluger \& DeNisi, 1998). These detrimental effects raise the counterintuitive possibility that deliberately foregoing information may enhance learning and, relatedly, performance (Huck, Szech, \& Wenner, 2015; Shen, Fishbach, \& Hsee, 2015). For instance, arousal might be particularly high and disadvantageous when comparisons with a rival are involved (Garcia, Tor, \& Schiff, 2013).

Another way in which deliberate ignorance may enable performance-and we admit that this idea is purely speculative-is the tendency to adopt an inside view when intuitively forecasting the future progress of a plan. According to Kahneman and Lovallo (1993), people tend to look at the unique details of a plan or project rather than focusing on the statistics of a class of past similar cases. This mind-set is typically regarded as bias, resulting in overly optimistic forecasts. Yet taking an inside view and deliberately ignoring outside information may be instrumental to reaching the decision to engage in an ambitious project. It is possible that no textbook would ever be written, no house built, and no opera composed if people based their decision on the progress and success of similar endeavors.

\section{Deliberate ignorance as a strategic device}

In economics, psychology, political science, and sociology, the reason most frequently invoked to explain why people do not always seek knowledge is strategic ignorance. Strategic ignorance has diverse functions; we discuss four of them (Fig. 1).

Since Schelling (1956), economists have investigated to what extent deliberate ignorance helps negotiators to gain a bargaining advantage (McAdams, 2012). Consider a situation in which one negotiator does not know how costly a breakdown in negotiations would be for both parties. Typically, there are multiple options for striking a successful deal, and each has a different degree of appeal for the negotiating parties. Both parties would generally prefer any of these options to a breakdown in negotiations. In game-theoretic terms, the typical bargaining situation puts negotiators in a "battle of the sexes." If one party opts not to know what a reasonable solution is, the burden of avoiding a stalemate rests with the informed bargainer, who is forced to make concessions from which the ignorant party stands to gain.

Forsaking information may even help both parties. If the information is likely to be ambiguous, for example, any egocentric bias in resolving this ambiguity may shrink the bargaining range (Loewenstein \& Moore, 2004). A number of experimental bargaining studies (and principle-agent situations; Crémer, 1995) have indeed shown that negotiating players may benefit from ignorance and that a nontrivial number of players deliberately decide to remain ignorant. This observation holds if players can hide their intention to remain ignorant (Conrads \& Irlenbusch, 2013).

Second, deliberate ignorance may function as a selfdisciplining device. This possibility is elaborated in Carrillo and Mariotti's (2000) theoretical analysis of a person with time-inconsistent preferences (i.e., a future incarnation of the self with other goals than the present self) with respect to consuming a good that exacts costs on future health. For instance, nonsmokers who believe the risk of lung cancer to be high may fear that seeing lower estimates would encourage them to smoke-and thus change their behavior in a way they will later regret.

Third, people can eschew responsibility for their actions by avoiding knowledge of how those actions and their outcomes affect others (or public goods such as the environment; Thunström, van't Veld, Shogren, \& Nordström, 2014). Studies using the dictator game have shown that the opportunity to avoid responsibility (by choosing to be ignorant of the recipient's payoffs) increases the proportion of selfish choices; conversely, when players cannot avoid responsibility, they render fairer (or more ethical) choices (Dana, 2006; Dana, Weber, \& Kuang, 2007). Eschewing moral responsibility through ignorance also helps to prevent cognitive dissonance-"often it is better not to know because if you did know, then you would have to act and stick your neck out" (Maslow, 1963 , p. 123). Utility-maximizing individuals may even be willing to pay to be shielded from information (Nyborg, 2011).

Fourth, choosing to remain ignorant can be a strategy for avoiding liability in a social or even a legal sense (Gross \& McGoey, 2015; McGoey, 2012b). It can be used in the context of institutional failures (e.g., ignorance of unauthorized trading or of the risks of highly speculative financial instruments; Davies \& McGoey, 2012), risky but lucrative business endeavors (e.g., ignorance of a new drug's adverse effects; McGoey, 2012a), or humanitarian catastrophes (Cohen, 2001; Maslow, 1963). As just one example, scientific communities, funding institutions, and lawmakers decide to leave some areas of inquiry unfunded because exploring them involves profound risks to the public (e.g., research on highly pathogenic avian influenza H5N1 viruses; Fouchier, García-Sastre, \& Kawaoka, 2012). Finally, policymakers may resist evidence-based evaluation of their policies because they do not want to be held responsible for failures. For instance, 
in recent years the German federal states have made it impossible for researchers to break down the data of the Programme for International Student Assessment (PISA) by state, thereby preventing scientists and the general public from comparing performance across federal states.

Let us briefly turn to the pervasive role of deliberate ignorance as a strategy for avoiding liability in legal affairs. There are few places where deliberate ignorance plays a more central role than in the courtroom. Under most rules of criminal law, it must be shown to the requisite standard that a defendant was aware of the facts that constitute the crime in question. For illustration, consider 18 U.S.C. § 1035 on social security fraud (see "False Statements Relating to Health Care Matters," n.d.): "(a) Whoever, in any matter involving a health care benefit program, knowingly and deliberately... makes any materially false, fictitious, or fraudulent statements or representations, ... shall be fined under this title or imprisoned not more than 5 years, or both" (emphasis added). This and other provisions require the determination of positive knowledge. A potential defendant may therefore avoid criminal liability simply by not acquiring knowledge. Legal systems sometimes seek to override this strategy (Robbins, 1990). For instance, the "ostrich instruction" tells jury members in U.S. courts that they may find the knowledge requirement to be satisfied by a defendant's willful ignorance of the relevant facts. Yet this instruction raises important questions, such as why the willfully blind actor is, in a normative sense, legally and morally culpable (Hellman, 2009) and what exactly the mental state of willful ignorance is (including the underlying motives; Sarch, 2014). Last but not least, how the legal system evaluates the implications of deliberate ignorance depends on who the bomo ignorans is. In the lawyer/ client relationship, the lawyer's deliberate ignorance is tacitly approved. It has been argued that attorneys, notwithstanding their obligations to the public, must be permitted in the interest of loyalty to their client not to seek out important information pertaining to the client's conduct. This practice has been argued to raise ethical issues (Roiphe, 2011).

\section{Deliberate ignorance as an impartiality and fairness device}

In his conception of a social contract, Rawls (1999) asked readers to place themselves in a hypothetical state of not knowing their place in society, or any other personal, social, or historical circumstances. Theoretically speaking, everyone thus shielded by a thick veil of ignorance from the temptation of pursuing their own special interests would agree on universal standards of fairness and justice. Beyond the realm of thought experiments, this veilof-ignorance method is used by, for instance, experimenters (in double-blind randomized trials; Kaptchuk, 1998), hiring boards, and courts to preempt bias. One example is blind auditioning in classical music. This fairly recent change in major orchestras' audition policies - the identity of candidates is now hidden by asking them to play behind a screen-has increased the probability of female musicians being hired, thus, substantially boosting the proportion of women in symphony orchestras (Goldin \& Rouse, 2000). ${ }^{3}$

\section{Deliberate ignorance as a cognitive-sustainability and information-management device}

In 2008, the average American was estimated to consume 100,500 words and 34 gigabytes $\left(10^{6}\right.$ bites) of information per day (Bohn \& Short, 2009). Though vast, this amount is small compared with what they might theoretically have consumed (Hilbert \& López, 2011). With the arrival of technologies and data-collecting devices such as predictive genetic testing, self-tracking devices (measuring, e.g., the number of bites per meal), ubiquitous computing, the Internet of Things, and myriad social media (e.g., Facebook, Twitter, WhatsApp), modern societies have entered a brave new world. Depending on one's perspective, it is either a paradise or a nether world where people drown in intractable amounts of information.

In this new world, countless actors (e.g., companies, advertisers, media, and policymakers) seek to colonize and appropriate people's attention. There is a risk that "hyperpalatable mental stimuli" designed to capture limited attentional resources will hijack the human mind, which evolved in a different information ecology (Crawford, 2015). By the same token, obesogenic environments now brim with inexpensive, convenient food products engineered to take consumers to their bliss point (i.e., the concentration of sugar or fat or salt at which sensory pleasure is maximized). Evolved to crave such hyperpalatable food, consumers risk losing control over what and how much they eat (Moss, 2013). Just as food engineers have become masters at hitting people's physical bliss points, the (social) media and internet companies have become experts in designing mental stimuli that commandeer people's attention (e.g., the Internet now hosts some 700-800 million individual porn pages; "Naked Capitalism," 2015). "Stimulation begets a need for more stimulation," and distractibility may be the mental equivalent of obesity (Crawford, 2015, p. 17). In an informationally fattening environment, citizens risk losing control over how they allocate their attention.

Alarm about information overload is arguably as old as the concept of information itself (Bell, 2010). Nevertheless, attending to a piece of information does exact opportunity costs: the choice to know one fact invariably implies 
not knowing other facts. For humans, who are hardwired to monitor their environment, the ability to allocate one's limited attentional resources reasonably is therefore becoming increasingly valuable in today's world. Indeed, the ability to select a few valuable pieces of information and deliberately ignore others may become a core cultural competence to be taught in school like reading and writing: "[A]n ability to ignore things would seem to remain important to the lifelong task of carving out and maintaining a space for rational agency for oneself, against the flux of environmental stimuli" (Crawford, 2015). ${ }^{4}$

We conclude this classification of types and functions of deliberate ignorance with a few observations. First, deliberate ignorance does not appear to be as peculiar a phenomenon as the cultural narrative about the insatiable human appetite for knowledge suggests. Second, in some domains (e.g., legal theory and practice), deliberate ignorance is constitutive and pervasive. Third, the present taxonomy is provisional and partial; other functions may be added once their essence is better understood (e.g., blind charity, that is, choosing to be ignorant about what is bad in other people; Driver, 2001). Fourth, most types and functions of deliberate ignorance are genuinely social phenomena (Hertwig, Hoffrage, \& ABC Research Group, 2013). Finally, in the age of information deluge, even informavores may appreciate deliberate ignorance as a way to maintain agency.

\section{When Is Deliberate Ignorance a Good Thing?}

Our taxonomy is descriptive. What about the normative perspective? Is deliberately ignoring information desirable for the individual and for society? By what normative standards is ignoring information to be assessed?

Approaching this question from a consequentialist perspective, one must identify and compare all foreseeable consequences of acquiring versus neglecting information-for the decision maker and for all others (potentially) affected by their choice. Take, for instance, health information. Although some researchers stress the individual and social harm of ignoring health information (Case, Andrews, Johnson, \& Allard, 2005; Sweeny et al., 2010), others emphasize the protective benefits of doing so (Shani et al., 2012; Yaniv et al., 2004). The balance between costs and benefits may depend on various subjective concerns and objective facts. One important variable is whether any action can be taken in response to the information obtained.

For illustration, let us return to James Watson, who declined information on his genetic predisposition to late-onset Alzheimer's, the disease thought to have claimed the life of his grandmother (Nyholt, Yu, \& Visscher, 2009). Watson perhaps thought that any benefits of knowing would be undone by the lack of medical treatment or cure available (Wheeler et al., 2008). Alternatively, he may have wanted to spare himself the dread of waiting for the onset of symptoms (Berns, 2006). Is the choice not to know irrational or ethically dubious? Some researchers have suggested that individuals have a right not to know in the context of genetic predictive testing, and various international conventions have recognized this right (Wehling, 2015). Others have argued that ignorance undermines self-governance (see Harris \& Keywood, 2001, and discussions in Bortolotti, 2012).

When ignoring information exposes others to risk (or imminent harm), Mill's harm principle may be invoked (Brink, 2014). Not picking up one's HIV test results may put future sexual partners or an unborn child at risk: If the disease is treated, it is far less likely to be transmitted. A hard-nosed welfare theorist would simply sum up the utilities of all possible consequences and-akin to the notion of "efficient breach of contract" (Cooter \& Ulen, 2008, pp. 262-268) - entertain the notion of "efficient ignorance": Provided the (expected) damage to the victim is smaller than the (present) gain for the person ignoring the information, society should approve of ignorance. It could do so by, for instance, exempting individuals who forego the opportunity to acquire that information from liability. Most noneconomists, however, find the concept of "efficient breach" repugnant (see Lewinsohn-Zamir, 2012). They are likely to see efficient ignorance in the same light, especially when the commodity in question is life and limb.

A distinction that is key to Mill's harm principle-that between consensual and nonconsensual harm-would also be a nonissue for the same adamant welfare theorist. Returning to our example of the unclaimed HIV test result, deliberate ignorance may cause consensual harm (to a consenting sexual partner aware of the risk) or nonconsensual harm (Brink, 2014). The welfare theorist would reason that a consenting individual has done so either because that person is indifferent to the risk or the individual has consented by receiving compensation (sex, to continue our example). Again, most people would part company with this argument, though they might accept truly voluntary consent as a justification for not claiming an HIV test result.

In other cases, the welfare balance seems straightforward. If there is a risk of liability, an individual may wish to forgo information that institutions (e.g., employers, courts) or society at large will want to be known. The opposite may be true in jury decision making. An individual juror may be curious (Loewenstein, 1994) or expect some private reward for finding out specific information (Kang et al., 2009). Society, however, wants courts to be impartial and therefore enforces ignorance (e.g., by barring character evidence; see "Character Evidence," n.d.). 
If the information to be deliberately ignored is unsolicited, the normative question shifts from the legitimacy of not acquiring or using available information to the right to protect oneself against information intrusion. Many diagnostic tests inevitably produce surplus medical information that "more often than not, would have been left undiscovered" because the abnormality would not have bothered the patient during her lifetime. The problem is that once, say, a microcarcinoma has been discovered, it "cannot easily be ignored" (Volk \& Ubel, 2011, p. 487), either by worried patients or by doctors faced with a litigious environment. More generally, in a medical environment that encourages excessive, often ineffective, and sometimes harmful medical care (Welch, 2015), a right not to know may, paradoxically, be a fundamental right of the fully informed patient. Pondering the decision (not) to know before the information is available puts people in a double bind: They have to work out how much they want to know a piece of information before knowing what it conveys (Rosenbaum, 2015). Once the information is known, the choice to ignore it may-for psychological and institutional reasons-be very difficult.

The normative assessment of instances of deliberate ignorance is even more complex when the decision (not) to seek or use knowledge is taken on behalf of someone else (e.g., predictive genetic testing in childhood; Bloch \& Hayden, 1990), that is, when one person's right (desire) to know clashes with another's right (desire) not to know. For instance, a mother may not want to know who adopted her child, but the adopted child may want to know who is her biological mother.

To conclude, there is no ready-made answer to the question of when deliberate ignorance is a beneficial, rational, or ethically appropriate. Each class of instances must be assessed on its own merits. As we will see shortly, several variants of strategic ignorance can be modeled as the rational behavior of a utility-maximizing agent. A rational (Bayesian) agent ${ }^{5}$ may even - counter to Good's (1967) advice-pay money not to see cost-free information (see Kadane, Schervish, \& Seidenfeld, 2008; Pedersen \& Wheeler, 2013); institutional arrangements (e.g., in the courtroom) may enforce deliberate ignorance in the service of impartiality. Of course, there is also a sinister side to deliberate ignorance, such as when it is used to evade responsibility, escape liability, or defend anti-intellectualism.

Finally, let us emphasize that the normative benchmark for the ethics of deliberate ignorance need not be utilitarian or consequentialist. Arguments extolling the desirability of (more) knowledge appear so intuitively persuasive because they invoke a very different normative ideal. Ever since the Enlightenment, knowledge has not only had instrumental but also moral value. Our understanding is that deliberate ignorance is not per se rational or irrational, ethical or unethical. Instead, deliberate ignorance is a cognitive tool whose success-measured in terms of individual or collective welfare-requires renewed analysis of both the actor and the environment (Arkes, Gigerenzer, \& Hertwig, 2016; Todd, Gigerenzer, \& the ABC Research Group, 2012; Todd et al., 2012). Such an analysis of the ecological rationality of deliberate ignorance may also add a new dimension to the motto of the Enlightenment, Kant's (1784) sapere audé (dare to use your own reason). The struggle for personal freedom and self-determination requires emancipation through knowledge and the courage to use one's own reason. In a world in which knowledge (information) is not unconditionally advantageous, however, using one's own reason can also mean choosing not to know.

Research on the psychology of deliberate ignorance is in its infancy. The objective of the first part of this article was to demonstrate that it is an endeavor worth pursuing. We also offered a taxonomy-a first structure for categorizing the dazzling variety of cases of deliberate ignorance. In addition, we sought to complement the is with a discussion of the ought: How ought one think about individuals' choosing not to acquire information, even though that information is available? Our treatment is but a first step; many more are necessary. We conclude with a roadmap for the next steps to be undertaken-by us, and hopefully by others.

\section{A Roadmap for Research on Deliberate Ignorance}

What motivates individuals to do without information? What are the cognitive strategies underlying their choice? Ideally, a better theoretical understanding of the phenomenon of deliberate ignorance will lead to testable propositions. What are the most promising empirical strategies for testing these propositions? What are the discernible policy implications? In the following, we address each of these milestones of our roadmap in turn.

\section{Theorizing deliberate ignorance}

Deliberately ignoring information is a choice. Economics offers a comprehensive choice theory and, thus, seems to be a natural candidate for an encompassing theoretical framework of deliberate ignorance. Specifically, canonical economic models take preferences as given and aim to explain choices by properties of the opportunity structure. Furthermore, economic agents are assumed to optimize - that is, to act as if they weigh (marginal) cost against (marginal) benefit. If this framework is to be adopted for deliberate ignorance, it is therefore 
necessary to specify all expected benefits from (not) acquiring information, as well as all expected costs.

What is the role of information in this framework? According to the classic economics of information perspective, individuals derive utility not from information per se but from its potential material consequences (Stigler, 1961). Recent findings and theorizing have led to the emergence of a different view: Beliefs and information, the time of information, and even its avoidance can be a source of pleasure and pain (Berns, 2006; Grant, Kajii, \& Polak, 1998; Karlsson et al., 2009; Kreps \& Porteus, 1978). Furthermore, the utility individuals derive from an outcome may depend on their anticipatory feelings (e.g., anxiety, hope) about it (anticipatory utility; Eliaz \& Spiegler, 2006; Loewenstein, 1987) or the anticipated emotional responses (e.g., disappointment) to information (e.g., bad news; Fels, 2015). In the context of information, this could explain individual time preferences: Someone may want to bring forward an unpleasant experience (information) to shorten the period of dread but to delay a pleasant experience (information) to savor the anticipation of it.

The economic framework also accommodates individual-specific aspects of the decision maker that may shape the choice (not) to know. These include the individual attitude to risk (the prospect of obtaining a piece of information can be seen as equivalent to entering a risky gamble for an anticipated payoff), the individual degree of patience (or lack thereof), and the individual anticipation of strategic actions taken by other interested actors. Moreover, the framework accommodates environmentspecific aspects, such as availability of an effective cure (Fels, 2015).

Despite these obvious strengths, we do not believe that the economic framework will suffice to explain and predict deliberate ignorance, for several reasons. First, it depicts humans as "superrational" beings who swiftly (marginally) respond to subtle changes in the opportunity structure. In so doing, the economic framework assumes consistent preferences across time. However, do and can individuals truly anticipate how much their future selves will regret not acquiring a piece of information? Take the example of optimal spending of one's assets after retirement. Over the 20th century, there was a remarkable gain in life expectancy of about 30 years in regions such as Western Europe and the United States (Christensen, Doblhammer, Rau, \& Vaupel, 2009). It is not unlikely that some very old individuals, somewhat surprised by their longevity, will regret that they were not warned against spending too much of their savings in the years immediately after retirement.

Second, the economic choice model can describe a choice (not) to know in terms of the maximization of some kind of expected utility. However, without theories of what individuals care about in specific domains of life-recall James Watson's and Günther Grass's choices not to know-it will be hard to predict what utility a person aims to maximize. Third, it will become even more problematic if people have time-inconsistent preferences because they inaccurately anticipate the costs and benefits of their choice (not) to know. Yet research from affective forecasting suggests that such inconsistencies will occur. When mentally simulating future events, people tend to overestimate the duration of their affective reactions, especially to negative events (e.g., a positive HIV test result), thus, fostering information avoidance (Gilbert \& Wilson, 2007). Relatedly, it has been argued that people take the more intense acquisition experience (obtaining information such as a negative medical test result) to predict consumption experience (the subsequent day-today experience of knowing that one is HIV positive). Consequently, people may overestimate the negative consequences of finding things out (Hsee, Hastie, \& Chen, 2008).

Still another important limitation of the expected utility framework is that it implies complex estimations and computations. Therefore, it is commonly interpreted to be an as-if model, that is, a model of the behavioral outcome but not of the actual cognitive, affective, or motivational processes. A radical deviation from this as-if approach is the thesis that individuals, unable to implement complex processes, instead rely on heuristics. One good reason to posit that at least some types of deliberate ignorance are best understood in terms of heuristics is the observed impact of emotions. Affect-rich stimuli have been demonstrated to prompt lexicographic heuristic processing (Suter, Pachur, \& Hertwig, in press; Suter, Pachur, Hertwig, Endestad, \& Biele, 2015); that is, in affect-rich contexts, one or a few top-ranked reasons, concerns, or motives-rather than an extensive (compensatory) cost-benefit calculus-may determine the choice to know or not to know.

Would use of a heuristic process rather than expected utility maximization render the choice of deliberate ignorance irrational? Indeed, some researchers have conceptualized the heuristics that people use as error-prone (Kahneman, 2011). Another view says that even if people could implement a complex utility-maximization calculus, they would often prefer to use heuristics to save mental effort, at the price of sacrificing some accuracy (utility; Payne, Bettman, \& Johnson, 1993). A third view suggests that heuristic processing of reasons, concerns, and motives can result in choices that are adaptive and ecologically rational (Gigerenzer, Hertwig, \& Pachur, 2011). Whichever view prevails, we believe that to evaluate acts of deliberate ignorance as advantageous or disadvantageous, it will be necessary to examine how instrumental those acts are in achieving the person's functional goals—rather 
than evaluating whether they rely on utility maximization calculus and its exacting assumptions (e.g., consistency across time; Arkes et al., 2016).

Let us conclude this section with another thought on the parallels between deliberate ignorance and forgetting. Forgetting is a process through which previously encoded information is discarded, and this process is key to the efficacy of the human memory. As James (1890) famously wrote, "In the practical use of our intellect, forgetting is as important a function as recollecting" (p. 679). Researchers have since determined how forgetting fosters decision processes such as the accuracy of inference heuristics (Schooler \& Hertwig, 2005) and serves key adaptive functions including, again, emotion regulation, through the selective forgetting of negative memories at the moment of both encoding and retrieval (see Nørby, 2015). In fact, one may speculate that the adaptive functions of forgetting are not so different from (some of) the functions of deliberate ignorance. We are not aware of an encompassing memory theory that could generate all adaptive functions of memory loss (Nørby, 2015). Similarly, we are not aware of any encompassing theory of deliberate ignorance that would or could generate its various functions.

\section{Measuring deliberate ignorance}

In all likelihood, our taxonomy will continue to grow as knowledge of deliberate ignorance grows. Its purpose is to organize, not to generate directly testable propositions. But the many phenomena that can be subsumed to deliberate ignorance invite more specific, testable propositions. Generating these hypotheses is why theorizing on the phenomenon is so important.

These hypotheses can be tested in several ways. One is by means of survey data. For instance, Hertwig, Schupp, and Woike (2016) presented a representative sample of some 2,000 participants living in Germany with a wide range of hypothetical scenarios and asked them whether or not they would like to know, for instance, the exact date of their death. About $90 \%$ did not want to know. More than $50 \%$ said they would not undertake genetic testing to find out whether they had an incurable genetic disease. Surveys can thus help to measure the prevalence of and preferences for deliberate ignorance.

A complementary approach is to experimentally test the reality of specific types of deliberate ignorance. For instance, Conrads and Irlenbusch (2013) examined strategic ignorance (in terms of a bargaining advantage) in a take-it-or-leave-it ultimatum bargaining context. Their set-up involved a proposer, who chose between two possible offers, and a responder, who accepted or rejected the offer made. Ignorance conferred an advantage: Responders accepted nearly all offers, including those that were unfavorable to them, when payoffs were not transparent to the proposer. Furthermore, about a quarter of proposers chose to stay in the dark about the properties of the payoffs.

A third measurement approach is to harness field data. As mentioned, up to $55 \%$ of people tested for HIV do not return to find out their result (Hightow et al., 2003). Some East Germans went on public record saying that they had no intention of consulting their Stasi files. How prevalent is this choice? The answer may lie in the Stasi Records Agency's (anonymized) user data.

All three approaches-surveys, experiments, and field studies-also promise to enrich the scientific community's knowledge of the personality dimensions (e.g., risk attitude, moral attitudes, curiosity, sensitizer vs. repressor coping styles, and aspiration levels ${ }^{6}$ ) and environmental factors (e.g., availability of medical treatment for an incurable disease) that predict people's information preferences. The survey findings of Hertwig et al. (2016) indicated that age appears to be a key factor. Older people are more inclined to choose not to know. Deliberate ignorance may thus be a mental tool that older people draw on to prune negativity from their lives (Carstensen, 2006; Carstensen, Isaacowitz, \& Charles, 1999).

\section{Deliberate ignorance as a challenge for policy makers}

As work on the psychology of deliberate ignorance is in its infancy, it seems premature to derive policy implications. But it is not too early to speculate. Some types of deliberate ignorance appear to have immediate prescriptive implications. Consider, for example, deliberate ignorance as an impartiality and fairness device (Fig. 1). If decision makers (e.g., jurors, hiring committees) agree that some information ought not to affect their deliberations but would, if available, likely bias them, then insulating themselves from this information would be a reasonable course of action. A deliberate veil of ignorance may, thus, be a tool worth harnessing systematically across a wide range of institutional selection processes.

Earlier in this article, we suggested that the ability to select information while deliberately ignoring other information might become a core cultural competence in informationally fattening environments. If so, the building blocks of this competence and how they could be taught at school and elsewhere will need to be studied. Without this research, one can only speculate as to which aspects are important and teachable. A first step would be to reverse engineer the work of those who design information, in the same way as the work of food engineers is currently being reversed engineered (Moss, 2013). How do these attention robbers manage to get 
people hooked? By understanding their methods, researchers may be able to derive strategies for resisting them and maintaining the level of agency and autonomy that most people want and need.

\section{To Know, or Not to Know? That Is the Question}

Psychology has been enhanced by processes of knowledge acquisition and human curiosity. The desire not to know, in contrast, is poorly understood. In our view, deliberate ignorance is not simply an "anomaly in human behavior" (Case et al., 2005, p. 354). It is prevalent, and nuanced psychological theories are required to understand it. The phenomenon of deliberate ignorance also raises various important questions. Answering these questions promises a deeper understanding of how people reckon with uncertainty and, indeed, sometimes prefer it to certainty. We believe that the study of deliberate ignorance may become a new scientific frontier of great importance. If so, it would represent a promising opportunity for multiple disciplines to work together to examine the cognitive and emotional underpinnings; rationality; ethics; and sociocultural, institutional, and political implications of deliberate ignorance.

\section{Acknowledgments}

This manuscript benefited enormously from helpful comments by Gordon Brown, Dagmar Ellerbrock, Werner Güth, Yaakov Kareev, Alexander Koch, Joachim Krueger, Tomás Lejarraga, Georg Nöldeke, Arthur Paul Pedersen, and Jan K. Woike. We are grateful to Susannah Goss and Valerie Chase for editing the manuscript and to Katja Münz for conducting the literature search.

\section{Declaration of Conflicting Interests}

The authors declared that they had no conflicts of interest with respect to their authorship or the publication of this article.

\section{Funding}

This research was supported by Grant HE 2768/7-2 from the German Research Foundation (DFG) to Ralph Hertwig.

\section{Notes}

1. We use the term bomo ignorans rather than bomo ignoramus to emphasize the deliberate act of not knowing and to avoid the negative connotations of the latter.

2. Maximizing suspense and surprise could also be interpreted as an instance of emotion regulation. Yet the two categories are quite distinct in nature. Information about what happens to a character in a movie or a novel has no obvious instrumental value, for instance, whereas information about a person's own health certainly does: That person can optimally condition her subsequent behavior on what she has learned. Collapsing both categories into one would, thus, obscure important distinctions.
3. Legal institutions sometimes also shield individuals from information deemed to compromise objectives such as impartiality. U.S. law, for instance, treats the defendant's criminal record as character evidence. In criminal proceedings that determine a defendant's guilt (often by a jury), evidence of a person's character or character traits-including a criminal record-is not admissible (with important exceptions). The criminal record may and does play a crucial role, however, when it comes to determining a convicted defendant's sentence (Federal Rules of Evidence, Rule 404; https://www.law.cornell.edu/rules/fre). In German law, in contrast, the defendant's criminal record is routinely introduced into legal proceedings (Bundeszentralregistergesetz $\$ 41$; http://www.gesetze-im-internet.de/bzrg/)

4. The notion that individuals have limited information-processing capacity and therefore cannot possibly attend to the vast amount of information the world offers is the starting premise of rational inattention theory (e.g., Sims, 2003). According to this economic theory, which measures information as reduction in uncertainty and uncertainty in terms of entropy, decision makers choose optimally in terms of which information they attend to. Assuming this optimal allocation were psychologically plausible, one key question for the future is to what extent it is still plausible and feasible in a world full of hyperpalatable mental stimuli.

5. A Bayesian agent tries to maximize the expected utility of his actions and estimates and updates expectation based on new information and in accordance with Bayes's rule.

6 . The ability to exercise deliberate ignorance may also be a psychological building block within models of boundedly rational decision making. One form of bounded rationality is Simon's (1956, 1990) concept of satisficing. Satisficing describes a class of methods for making a choice from a set of options encountered sequentially when an individual does not know which options are yet to come. Satisficing means setting an adjustable aspiration level and ending the search for the desired option as soon as an option that exceeds this level presents itself. For instance, suppose a waiter rattles off a list of entrées. Satisficing would mean stopping the waiter when a "good enough" option has been encountered, thus, deliberately ignoring all the other options.

\section{References}

Abbott, A. (2010). Varieties of ignorance. The American Sociologist, 41, 174-189. doi:10.1007/s12108-010-9094-x

Akerlof, G., \& Dickens, W. (1982). The economic consequences of cognitive dissonance. American Economic Review, 72, 307-319.

Anderson, M. C., \& Green, C. (2001). Suppressing unwanted memories by executive control. Nature, 410, 366-369. doi: $10.1038 / 35066572$

Arkes, H. R., Gigerenzer, G., \& Hertwig, R. (2016). How bad is incoherence? Decision, 3, 20-39. doi:10.1037/dec0000043

Bell, V. (2010, February). Don't touch that dial! A history of media technology scares, from the printing press to Facebook. Slate. Retrieved from http://www.slate.com/ articles/health_and_science/science/2010/02/dont_touch_ that_dial.html

Bellarmine, R. (1989). The art of dying well. In J. D. Donnelly \& R. J. Teske (Eds. \& Trans.), Spiritual writings (pp. 235-386). Mahwah, NJ: Paulist Press. 
Berns, G. S. (2006, May 5). Neurobiological substrates of dread. Science, 312, 754-758. doi:10.1126/science.1123721

Blackwell, D. (1953). Equivalent comparisons of experiments. The Annals of Mathematical Statistics, 24, 265-272. doi:10.1214/aoms/1177729032

Bloch, M., \& Hayden, M. R. (1990). Predictive testing for Huntington disease in childhood: Challenges and implications. American Journal of Human Genetics, 46, 1-4. doi:10.1086/514873

Bohn, R. E., \& Short, J. E. (2009). How much information? 2009 Report on American Consumers. Global Information Industry Center, University of California, San Diego. Retrieved from http://group47.com/HMI_2009_ ConsumerReport_Dec9_2009.pdf

Bortolotti, L. (2012). The relative importance of undesirable truths. Medicine, Health Care and Philosophy, 16, 683-690. doi:10.1007/s11019-012-9449-x

Brink, D. (2014, August). Mill's moral and political philosophy. The Stanford Encyclopedia of Philosophy. Retrieved from http://plato.stanford.edu/entries/mill-moral-political/

Carnap, R. (1947). On the application of inductive logic. Philosophy and Phenomenological Research, 8, 133-148. doi: $10.2307 / 2102920$

Carrillo, J. D., \& Mariotti, T. (2000). Strategic ignorance as a selfdisciplining device. The Review of Economic Studies, 67, 529-544. doi:10.1111/1467-937x.00142

Carstensen, L. L. (2006, June 30). The influence of a sense of time on human development. Science, 312, 1913-1915. doi:10.1126/science. 1127488

Carstensen, L. L., Isaacowitz, D. M., \& Charles, S. T. (1999). Taking time seriously: A theory of socioemotional selectivity. American Psychologist, 54, 165-181. doi:10.1037/0003066x.54.3.165

Case, D. O., Andrews, J. E., Johnson, J. D., \& Allard, S. L. (2005). Avoiding versus seeking: The relationship of information seeking to avoidance, blunting, coping, dissonance, and related concepts. Journal of the Medical Library Association, 93, 353-362.

Character evidence; crimes or other acts. Rule 404. (n.d.). Legal Information Institute. Retrieved from https://www.law.cor nell.edu/rules/fre/rule_404

Christensen, K., Doblhammer, G., Rau, R., \& Vaupel, J. W. (2009). Ageing populations: The challenges ahead. The Lancet, 374, 1196-1208. doi:10.1016/s0140-6736(09)61460-4

Cohen, S. (2001). States of denial: Knowing about atrocities and suffering. Cambridge, England: Polity Press.

Conrads, J., \& Irlenbusch, B. (2013). Strategic ignorance in ultimatum bargaining. Journal of Economic Behavior E Organization, 92, 104-115. doi:10.1016/j.jebo.2013 .05 .010

Cooter, R., \& Ulen, T. (2008). Law and economics (5th ed.). Boston, MA: Pearson Education.

Crawford, M. B. (2015). The world beyond your head: On becoming an individual in an age of distraction. New York, NY: Farrar, Straus and Giroux.

Creighton, S., Almqvist, E. W., MacGregor, D., Fernandez, B., Hogg, H., Beis, J., . . . Hayden, M. R. (2003). Predictive, prenatal and diagnostic genetic testing for Huntington's disease: The experience in Canada from 1987 to 2000. Clinical Genetics, 63, 462-475. doi:10.1034/j.1399-0004 .2003.00093.x

Crémer, J. (1995). Arm's length relationships. The Quarterly Journal of Economics, 110, 275-295. doi:10.2307/2118440

Dana, J. (2006). Strategic ignorance and ethical behavior in organizations. In A. E. Tenbrunsel (Ed.), Ethics in groups (pp. 39-57). Bingley, England: Emerald Group. doi:10.1016/ s1534-0856(06)08003-0

Dana, J., Weber, R. A., \& Kuang, J. X. (2007). Exploiting moral wiggle room: Experiments demonstrating an illusory preference for fairness. Economic Theory, 33, 67-80. doi:10.1007/ s00199-006-0153-Z

Daston, L., \& Park, K. (2001). Wonders and the order of nature 1150-1750. New York, NY: Zone Books.

Davies, W., \& McGoey, L. (2012). Rationalities of ignorance: On financial crisis and the ambivalence of neo-liberal epistemology. Economy and Society, 41, 64-83. doi:10.1080/030 85147.2011.637331

Driver, P. (2001). Uneasy virtue. Cambridge, England: Cambridge University Press.

Eliaz, K., \& Spiegler, R. (2006). Can anticipatory feelings explain anomalous choices of information sources? Games and Economic Behavior, 56, 87-104. doi:10.1016/ j.geb.2005.06.004

Elster, J. (1996). Rationality and the emotions. The Economic Journal, 106, 1386-1397. doi:10.2307/2235530

Ely, J., Frankel, A., \& Kamenica, E. (2015). Suspense and surprise. Journal of Political Economy, 123, 215-260. doi:10.1086/677350

False statements relating to health care matters, 18 U.S. Code $\S$ 1035. (n.d.). Retrieved from https://www.law.cornell.edu/ uscode/text/18/1035

Fels, M. (2015). On the value of information: Why people reject medical tests. Journal of Behavioral and Experimental Economics, 56, 1-12. doi:10.1016/j.socec.2015.02.006

Fouchier, R. A. M., García-Sastre, A., \& Kawaoka, Y. (2012). Pause on avian flu transmission studies. Nature, 481, 443. doi:10.1038/481443a

Freud, S. (1950). Remembering, repeating and working-through. In J. Strachey (Ed. \& Trans.), The standard edition of the complete psychological works of Sigmund Freud (Vol. XII, pp. 145-157). London, England: Hogarth. (Original work published 1914)

Garcia, S. M., Tor, A., \& Schiff, T. M. (2013). The psychology of competition: A social comparison perspective. Perspectives on Psychological Science, 8, 634-650. doi:10.1177/1745691613504114

Gigerenzer, G., Hertwig, R., \& Pachur, T. (Eds.). (2011). Heuristics: The foundations of adaptive behavior. New York, NY: Oxford University Press.

Gilbert, D. T., \& Wilson, T. D. (2007, September 7). Prospection: Experiencing the future. Science, 317, 1351-1354. doi:10.1126/science.1144161

Goldin, C., \& Rouse, C. (2000). Orchestrating impartiality: The impact of "blind" auditions on female musicians. The American Economic Review, 90, 715-741. doi:10.1257/ aer.90.4.715 
Good, I. J. (1967). On the principle of total evidence. British Journal for the Philosophy of Science, 17, 319-321. doi:10.1093/bjps/17.4.319

Grant, S., Kajii, A., \& Polak, B. (1998). Intrinsic preference for information. Journal of Economic Theory, 83, 233-259. doi:10.1006/jeth.1996.2458

Gray, T. (1747). Ode on a distant prospect of Eton College. Thomas Gray Archive. Retrieved from http://www.thomasgray.org/cgi-bin/display.cgi?text=odec

Gross, M., \& McGoey, L. (Eds.). (2015). Routledge international handbook of ignorance studies. Basingstoke, England: Taylor \& Francis.

Hage, V., \& Thimm, K. (2010, August 16). Oralverkehr mit Vokalen [Oral sex with vowels]. Spiegel Online. Retrieved from http://www.spiegel.de/spiegel/a-711869-4.html

Harris, J., \& Keywood, K. (2001). Ignorance, information and autonomy. Theoretical Medicine and Bioethics, 22, 415436. doi:10.1023/a:1013058801622

Hart, W., Albarracín, D., Eagly, A. H., Brechan, I., Lindberg, M. J., \& Merrill, L. (2009). Feeling validated versus being correct: A meta-analysis of selective exposure to information. Psychological Bulletin, 135, 555-588. doi:10.1037/ a0015701

Hellman, D. (2009). Willfully blind for good reason. Criminal Law and Philosophy, 3, 301-316. doi:10.1007/s11572-0099080-y

Hertwig, R., Hoffrage, U., \& ABC Research Group. (2013). Simple heuristics in a social world. New York, NY: Oxford University Press.

Hertwig, R., Schupp, J., \& Woike, J. K. (2016). The reality and prevalence of not wanting to know. Manuscript in preparation.

High, C., Kelly, A. H., \& Mair, J. (2012). The antbropology of ignorance: An ethnographic approach. New York, NY: Palgrave Macmillan.

Hightow, L. B., Miller, W. C., Leone, P. A., Wohl, D., Smurzynski, M., \& Kaplan, A. H. (2003). Failure to return for HIV posttest counseling in an STD clinic population. AIDS Education and Prevention, 15, 282-290. doi:10.1521/ aeap.15.4.282.23826

Hilbert, M., \& López, P. (2011, April 1). The world's technological capacity to store, communicate, and compute information. Science, 332, 60-65. doi:10.1126/science.1200970

Hobbes, T. (1968). Leviathan (C. B. Macpherson, Ed.). London, England: Penguin. (Original work published 1651)

Howell, J. L., \& Shepperd, J. A. (2012). Reducing information avoidance through affirmation. Psychological Science, 23, 141-145. doi:10.1177/0956797611424164

Howell, J. L., \& Shepperd, J. A. (2013). Reducing health-information avoidance through contemplation. Psychological Science, 24, 1696-1703. doi:10.1177/0956797613478616

Hsee, C. K., Hastie, R., \& Chen, J. (2008). Hedonomics: Bridging decision research with happiness research. Perspectives on Psychological Science, 3, 224-243. doi:10.1111/j.17456924.2008.00076.x

Huck, S., Szech, N., \& Wenner, L. M. (2015). More effort with less pay: On information avoidance, belief design and performance (Working Paper Series in Economics, Karlsruher Institut für Technologie (KIT), No. 72). Retrieved from http://econstor.eu/bitstream/10419/120879/1/836112962 .pdf

Hutcherson, C. A., \& Gross, J. J. (2011). The moral emotions: A social-functionalist account of anger, disgust, and contempt. Journal of Personality and Social Psychology, 100, 719-737. doi:10.1037/a0022408

James, W. (1890). The principles of psychology (Vol. 1). New York, NY: Holt.

Jones, S. (2014). The media of testimony: Remembering the East German Stasi in the Berlin Republic. Basingstoke, England: Palgrave Macmillan.

Kadane, J. B., Schervish, M., \& Seidenfeld, T. (2008). Is ignorance bliss? The Journal of Philosophy, 105, 5-36. doi:10.5840/ jphil200810518

Kahneman, D. (2011). Thinking, fast and slow. New York, NY: Farrar, Straus and Giroux.

Kahneman, D., \& Lovallo, D. (1993). Timid choices and bold forecasts: A cognitive perspective on risk taking. Management Science, 39, 17-31.

Kang, M. J., Hsu, M., Krajbich, I. M., Loewenstein, G., McClure, S. M., Wang, J. T., \& Camerer, C. F. (2009). The wick in the candle of learning: Epistemic curiosity activates reward circuitry and enhances memory. Psychological Science, 20, 963-973. doi:10.1111/j.1467-9280.2009.02402.x

Kant, I. (1784). Beantwortung der Frage: Was ist Aufklärung? [Answering the question: What is Enlightenment?]. Berlinische Monatsschrift, 4, 481-494.

Kaptchuk, T. J. (1998). Intentional ignorance: A history of blind assessment and placebo controls in medicine. Bulletin of the History of Medicine, 72, 389-433. doi:10.1353/ bhm.1998.0159

Karlsson, N., Loewenstein, G., \& Seppi, D. (2009). The ostrich effect: Selective attention to information. Journal of Risk and Uncertainty, 38, 95-115. doi:10.1007/s11166-009-9060-6

Kluger, A. N., \& DeNisi, A. (1996). The effects of feedback interventions on performance: Historical review, a metaanalysis and a preliminary feedback intervention theory. Psychological Bulletin, 119, 254-284. doi:10.1037/00332909.119.2.254

Kluger, A. N., \& DeNisi, A. (1998). Feedback interventions: Toward the understanding of a double-edged sword. Current Directions in Psychological Science, 7, 67-72. doi:10.1111/1467-8721.ep10772989

Kreps, D. M., \& Porteus, E. L. (1978). Temporal resolution of uncertainty and dynamic choice theory. Econometrica, 46, 185-200. doi:10.2307/1913656

Lewinsohn-Zamir, D. (2012). The questionable efficiency of the efficient breach doctrine. Journal of Institutional and Theoretical Economics, 168, 5-26. doi:10.1628/ 093245612799440014

Loewenstein, G. (1987). Anticipation and the valuation of delayed consumption. The Economic Journal, 97, 666-684. doi: $10.2307 / 2232929$

Loewenstein, G. (1994). The psychology of curiosity: A review and reinterpretation. Psychological Bulletin, 116, 75-98. doi:10.1037/0033-2909.116.1.75

Loewenstein, G., \& Moore, D. A. (2004). When ignorance is bliss: Information exchange and inefficiency in bargaining. The Journal of Legal Studies, 33, 37-58. doi:10.1086/382581 
Marshall, G. (2014). Don't even think about it: Why our brains are wired to ignore climate change. New York, NY: Bloomsburg.

Martinelli, C. (2006). Would rational voters acquire costly information? Journal of Economic Theory, 129, 225-251. doi:10.1016/j.jet.2005.02.005

Maslow, A. H. (1963). The need to know and the fear of knowing. The Journal of General Psychology, 68, 111-125. doi:1 0.1080/00221309.1963.9920516

McAdams, D. (2012). Strategic ignorance in a second-price auction. Economics Letters, 114, 83-85. doi:10.1016/j.econlet.2011.09.036

McGoey, L. (2012a). The logic of strategic ignorance. The British Journal of Sociology, 63, 533-576. doi:10.1111/j.14684446.2012.01424.x

McGoey, L. (2012b). Strategic unknowns: Towards a sociology of ignorance. Economy and Society, 41, 1-16. doi:10.1080/ 03085147.2011 .637330

Melnyk, D., \& Shepperd, J. A. (2012). Avoiding risk information about breast cancer. Annals of Behavioral Medicine, 44 , 216-224. doi:10.1007/s12160-012-9382-5

Merton, R. K. (1987). Three fragments from a sociologist's notebooks: Establishing the phenomenon, specified ignorance, and strategic research materials. Annual Review of Sociology, 13, 1-29. doi:10.1146/annurev.so.13.080187.000245

Modigliani, F. (1986, November 7). Life cycle, individual thrift, and the wealth of nations. Science, 234, 704-712. doi:10.1126/science.234.4777.704

Montagu, B. (Ed.). (1841). The works of Francis Bacon, Lord Chancellor of England. Philadelphia, PA: Carey and Hart.

Moore, W. E., \& Tumin, M. M. (1949). Some social functions of ignorance. American Sociological Review, 14, 787-795. doi: $10.2307 / 2086681$

Moss, M. (2013). Salt, sugar, fat: How the food giants hooked us. New York, NY: Random House.

Naked capitalism. (2015, September 26). The Economist. Retrieved from http://www.economist.com/news/interna tional/21666114-internet-blew-porn-industrys-businessmodel-apart-its-response-holds-lessons

Nørby, S. (2015). Why forget? On the adaptive value of memory loss. Perspectives on Psychological Science, 10, 551-578. doi: $10.1177 / 1745691615596787$

Nyborg, K. (2011). I don't want to hear about it: Rational ignorance among duty-oriented consumers. Journal of Economic Behavior \& Organization, 79, 263-274. doi:10.1016/j .jebo.2011.02.004

Nyholt, D. R., Yu, C. E., \& Visscher, P. M. (2009). On Jim Watson's APOE status: Genetic information is hard to hide. European Journal of Human Genetics, 17, 147-149. doi:10.1038/ejhg.2008.198

Payne, J. W., Bettman, J. R., \& Johnson, E. J. (1993). The adaptive decision maker. New York, NY: Cambridge University Press.

Pedersen, A. P., \& Wheeler, G. (2013). Demystifying dilation. Erkenntnis, 79, 1305-1342. doi:10.1007/s10670-013-9531-7

Proctor, R., \& Schiebinger, L. L. (Eds.). (2008). Agnotology: The making and unmaking of ignorance. Stanford, CA: Stanford University Press.
Rawls, J. (1999). A theory of justice (Rev. ed.). Cambridge, MA: Harvard University Press.

Robbins, I. P. (1990). The ostrich instruction: Deliberate ignorance as a criminal mens rea. The Journal of Criminal Law and Criminology, 81, 191-233. doi:10.2307/1143906

Roiphe, R. (2011). The ethics of willful ignorance. The Georgetown Journal of Legal Ethics, 24, 187-224. doi:10.2139/ssrn.2243849

Rosenbaum, L. (2015). The paternalism preference: Choosing unshared decision making. The New England Journal of Medicine, 373, 589-592. doi:10.1056/nejmp1508418

Ross, W. D. (Ed.). (1924). Aristotle's metaphysics. Oxford, England: Clarendon Press.

Sarch, A. F. (2014). Willful ignorance, culpability and the criminal law. St. John's Law Review, 88, 4. Retrieved from http:// scholarship.law.stjohns.edu/cgi/viewcontent.cgi?article= 6696\&context=lawreview

Schelling, T. C. (1956). An essay on bargaining. The American Economic Review, 46, 281-306.

Schneider, L. (1962). The role of the category of ignorance in sociological theory: An exploratory statement. American Sociological Review, 27, 492-508. doi:10.2307/2090030

Schooler, L. J., \& Hertwig, R. (2005). How forgetting aids heuristic inference. Psychological Review, 112, 610-628. doi:10.1037/0033-295x.112.3.610

Shani, Y., van de Ven, N., \& Zeelenberg, M. (2012). Delaying information search. Judgment and Decision Making, 7, 750-760.

Shen, L., Fishbach, A., \& Hsee, C. K. (2015). The motivatinguncertainty effect: Uncertainty increases resource investment in the process of reward pursuit. Journal of Consumer Research, 41, 1301-1315.

Silvia, P. J. (2008). Interest: The curious emotion. Current Directions in Psychological Science, 17, 57-60. doi:10.1111/ j.1467-8721.2008.00548.x

Simon, H. A. (1956). Rational choice and the structure of environments. Psychological Review, 63, 129-138. doi:10.1037/ h0042769

Simon, H. A. (1990). Invariants of human behavior. Annual Review of Psychology, 41, 1-19. doi:10.1146/annurev .psych.41.1.1

Sims, C. A. (2003). Implications of rational inattention. Journal of Monetary Economics, 50, 665-690. doi:10.1016/S03043932(03)00029-1

Stigler, G. J. (1961). The economics of information. Journal of Political Economy, 69, 213-225. doi:10.1086/258464

Suter, R. S., Pachur, T., \& Hertwig, R. (in press). How affect shapes risky choice: Distorted probability weighting versus probability neglect. Journal of Behavioral Decision Making. doi:10.1002/bdm.1888

Suter, R. S., Pachur, T., Hertwig, R., Endestad, T., \& Biele, G. (2015). The neural basis of risky choice with affective outcomes. PLOS ONE, 1O(4), e0122475. doi:10.1371/journal .pone.0122475

Sweeny, K., Melnyk, D., Miller, W., \& Shepperd, J. A. (2010) Information avoidance: Who, what, when, and why. Review of General Psychology, 14, 340-353. doi:10.1037/ a0021288 
Thunström, L., van't Veld, K., F. Shogren, J. F., \& Nordström, J. (2014). On strategic ignorance of environmental harm and social norms. Revue D'Economie Politique, 124, 195-214. doi: $10.3917 /$ redp. 242.0195

Todd, P. M., Gigerenzer, G., \& the ABC Research Group. (2012). Ecological rationality: Intelligence in the world. New York, NY: Oxford University Press.

Ullmann-Margalit, E. (2000). On not wanting to know. In E. Ullmann-Margalit (Ed.), Reasoning practically (pp. 72-84). New York, NY: Oxford University Press.

Ungar, S. (2008). Ignorance as an under-identified social problem. The British Journal of Sociology, 59, 301-326. doi:10.1111/j.1468-4446.2008.00195.x

Van Dijk, E., \& Zeelenberg, M. (2007). When curiosity killed regret: Avoiding or seeking the unknown in decisionmaking under uncertainty. Journal of Experimental Social Psychology, 43, 656-662. doi:10.1016/j.jesp.2006.06.004

Volk, M. L., \& Ubel, P. A. (2011). Better off not knowing. Improving clinical care by limiting physician access to unsolicited diagnostic information. Archives of Internal Medicine, 171, 487-488. doi:10.1001/archinternmed.2011.63
Wahlin, T. B. R. (2007). To know or not to know: A review of behaviour and suicidal ideation in preclinical Huntington's disease. Patient Education and Counseling, 65, 279-287. doi:10.1016/j.pec.2006.08.009

Wehling, P. (2015). Fighting a losing battle? The right not to know and the dynamics of biomedical knowledge production. In M. Gross \& L. McGoey (Eds.), Routledge international handbook of ignorance studies (pp. 206-214). Basingstoke, England: Taylor \& Francis.

Welch, H. G. (2015). Less medicine, more bealth: 7 assumptions that drive too much medical care. Boston, MA: Beacon Press.

Wheeler, D. A., Srinivasan, M., Egholm, M., Shen, Y., Chen, L., McGuire, A., . . . Rothberg, J. M. (2008). The complete genome of an individual by massively parallel DNA sequencing. Nature, 452, 872-876. doi:10.1038/ nature 06884

Yaniv, I., Benador, D., \& Sagi, M. (2004). On not wanting to know and not wanting to inform others: Choices regarding predictive genetic testing. Risk, Decision and Policy, 9, 317-336. doi:10.1080/14664530490896573 